\title{
A Critical Review of Wastewater Resource Recovery Implementation in Indonesia
}

\author{
Ni Nyoman Nepi Marleni $i^{1, *}$, Gema Sakti Raspati ${ }^{2}$ \\ ${ }^{1}$ Civil and Environmental Engineering Department, Universitas Gadjah Mada, Yogyakarta, INDONESIA \\ Jalan Grafika No 2 Yogyakarta \\ ${ }^{2}$ SINTEF Community, SINTEF, Trondheim, Norway \\ P.O. Box 4760 Torgarden, NO-7465 \\ *Corresponding authors: nepi.marleni@ugm.ac.id
}

SUBMITTED 20 December 2019 REVISED 1 January 2020 ACCEPTED 23 January 2020

\begin{abstract}
Wastewater has been recognized as a resource due to its large quantities, and it contains many valuable resources that can be converted into valuable material. Reusing or recovering resources from wastewater can reduce the environmental footprint of wastewater treatment, minimize the contamination and ensure the availability of valuable resources for the human being. The ultimate aim of wastewater resource recovery (WRR) is to create a sustainable and resilient community which is very relevant in Indonesia as this country experiences many natural or human-made disaster. To have an effective implementation, therefore, it is crucial to identify the barriers or supporting factors in its implementation of Wastewater Resource Recovery, which can be different for many regions. Through extensive literature studies, this study intends to review the possibility of WRR implementation in Indonesia. This study discusses Indonesia policy/regulation about wastewater management across all-region in Indonesia, identify barriers in WRR, compares global trends of wastewater management to Indonesia practice and list wastewater resources that potentially can be recovered in Indonesia. From the review, barriers of WRR implementation in Indonesia is most probably due to the policy and regulation of wastewater management which many of them did not support the option of WRR, instead of suggesting only safe discharge option. However, some regulations have mentioned the utilization of wastewater by-product, but it is limited only to treated water utilization. Other obstacles are social acceptance and distance between recovered material supply and demand. Social acceptance includes the human perception regarding the health risk associated with wastewater by-product. Religion also could be a potential barrier that needs to be handled in the implementation of WRR. This study could give new insight into the current state of wastewater resource recovery initiative in Indonesia; thus the strategy to overcome the barriers could be designed.
\end{abstract}

KEYWORDS Wastewater Resource Recovery; Wastewater Management; Decentralised and Centralised Wastewater System; Wastewater Reuse, Policy and Regulation

(c) The Author(s) 2020. This article is distributed under a Creative Commons Attribution-ShareAlike 4.0 International license.

\section{INTRODUCTION}

Indonesia is facing challenges due to its population growth which leads to finite natural resources. Population in Indonesia reached 280 million in 2017, with a population growth rate of $2 \%$ per year. It is estimated that two-thirds of the population in Indonesia will live in urban areas (BPS, 2013). High population growth and dense area put pressure on food security and any other resources used for sustaining human life. Moreover, high and dense population causes environmental issues owing to the high discharge of treated and untreated wastewater (GerbensLeenes, Nonhebel and Krol, 2010; Thornton,
2010; Cordell et al., 2011). Environmental degradation caused by untreated sewage has been increasing, although some reports may indicate stabilisation or even small improvements in only specific locations. According to the Ministry of Environment and Forestry in 2015, 75.2\% of rivers in Indonesia have been heavily polluted, and 22.5\% show a moderate level of pollution (Yudo and Said, 2017). Despite the wastewater discharge effect on pollution, it can also be viewed as a source for valuable materials needed by mankind. Water, energy, nutrients for fertiliser, bioplastics, cellulose, and many more can be recovered from 
the wastewater with proper treatment. Wastewater should not be discharged untreated, but it should be managed to gain its potential resources recovery and reusability (Kerstens et al., 2011; Braungart, McDonough and Bollinger, 2007; McDonough, 2000).

Wastewater resource recovery (WRR) is a concept of considering wastewater as a valuable resource since it contains many resources like organic matter, phosphorus, heavy metal, thermal energy that can be used as a source of many useful materials needed by humankind. Application of the resource recovery concepts in the planning stage introduces the circular resource management and circular economy which closes the cycle of waste and generates income for those involves in the recovery process (Agudelo-Vera et al., 2011) and circular economy which. sanitation approach should consider both 'front-end' and 'back-end' user. Front-end user refers to the provision of sanitation system while back-end user is a user who demands a sanitation product for assuring the long term operational and financial sustainability (Murray and Ray, 2010). The target of universal access to the sanitation facilities set by Sustainable Development Goals (SDGs) has urged the Government of Indonesia to provide wastewater treatment facilities massively. The concept of back-end user and circular resource management should be incorporated in the planning policy of wastewater management in Indonesia to encourage and assure many stakeholders understand and implement the concept in the future. Indeed, the Government of Indonesia has set a wastewater and solid waste plan for 2015-2019, however, it mainly covers solid waste management while wastewater management that includes its reuse/recovery potential is not clear (Bappenas, 2014). This study presents a brief overview related to some aspects that could be barrier or supporting factors in the implementation of wastewater resource recovery (WRR) in municipal or domestic wastewater. This study provides new insights into the current state of resource recovery initiative in Indonesia and how the country can cope with the global trend of resource recovery.
Through extensive literature studies, this study intends to review the current condition of wastewater management in Indonesia and to look into wastewater management policies and regulations across all-region in Indonesia. Data presented in this paper were obtained from several sanitation reports in Indonesia and research article papers. The number of literature collected in this study consist of regulation and standard document, sanitation reports, research and review articles. Few works of literature discussed specifically the potential of WRR application in Indonesia but limited to certain regions. The other research or review articles described the application of WRR in another country which can be used for a benchmarking for this study. Further, this study describes some potential resources that have been studied worldwide and potentially implemented in Indonesia. Some global trends of wastewater management were discussed as a benchmark for wastewater management in Indonesia.

\section{DOMESTIC WASTEWATER MANAGEMENT}

Water quality trends of rivers in Indonesia have been showing a steady decline in the past decade. According to data from the research conducted in 6 major rivers in Java, Sumatra, and Kalimantan, the largest sources of pollution came from nonpoint source pollutants, of which $55 \%$ of the pollutant originated from domestic sectors. Domestic wastewater is the most critical source of contamination of the surface water in the country (The World Bank; Australian Aid, 2013; Wahyu Wijaya, 2018; ADB, 2017; Yudo and Said, 2017). In the urban areas (110 million people), about $1 \%$ of the wastewater is safely collected and treated, and about $4 \%$ of the sewage is safely collected and safely disposed or treated. In rural areas (130 million people), wastewater is neither collected nor treated in 2016 (ADB, 2017). According to the study of the Ministry of Public Work and Housing, the pollution of surface water causes a significant increase in biochemical oxygen demand (BOD). Such an increase corresponds to an additional cost of water production of Rp. $9.17 / \mathrm{m}^{3}$ treated water for every $1 \mathrm{mg} / \mathrm{L} \mathrm{BOD} \mathrm{increment.} \mathrm{It} \mathrm{is}$ reported that the customers need to pay $25 \%$ 
extra for water supply provision (Ministrial Regulation No. 18/2007 about Development of Water Supply System).

Moreover, Indonesia ranks 3rd among Southeast Asian countries that have the highest case of open defecation (The World Bank; Australian Aid, 2013), which results in public health decline. World Bank's Water and Sanitation Program (WSP) estimates that Indonesia lost USD 6.6 billion in 2007 due to poor sanitation and this is equivalent to $2.4 \%$ of the gross domestic product (GDP) of the country (The World Bank; Australian Aid, 2013). Water-borne diseases cause 50,000 premature deaths and 120 million cases of the disease annually. Indonesia has the highest incidence of typhus in Asia, and around $70 \%$ of children have worms in their digestive system (AECOM International Development and Sandec, 2010).

The data collected in a study conducted by AusAid showed that two-thirds of the urban population in Indonesia acquire on-site wastewater treatment; however, one-sixth of on-site wastewater treatment types is borehole pit latrine with the unconfined and unsealed base layer (The World Bank; Australian Aid, 2013). Based on a survey of the existing and functioning septic tanks in households, many respondents stated that the septic tanks were never drained and have been in operation for more than five years. This implies that the septic tanks might leak and operate as borehole latrines instead (Afandi and Sunoko, 2013). In addition, $40 \%$ of the on-site wastewater treatment facilities are located less than 10 meters from community wells which serve as the primary water source for the neighbourhood (Bons et al., 2016). On-site wastewater treatment by using pit latrine causes direct seepage into the ground and, thus, potentially contributes to groundwater pollution. A study conducted by Worldbank \& Australian Aid (2013) found that $70 \%$ source of groundwater is contaminated by domestic on-site treatment. The main approach of municipal wastewater treatment has been 'discharge' oriented to waterbodies without considering any reuse/recycle concept (Ministrial Regulation
No.04/2017 about Domestic Wastewater Management; Local Regulation No. 13/2006 about Wastewater Mangement in the City of Samarinda; Governor Regulation of DKI Jakarta No. 122/2005 about Domestic Wastewater Management; Governor Regulation No. 2/2013 about Domestic Wastewater Management).

According to a study by Yudo \& Said (2017), Wijaya (2018) and AECOM International Development \& Sandec (2010), the challenges in the sanitation sector in Indonesia are amplified by a low public awareness and participation; lack of laws, regulations, standards, standardised operating manuals, and enforcement of existing policies in Indonesia related to the waste management; the absence of framework and tools to help decision-makers determine their decisions effectively, efficiently and on target; there are gaps in regulations and laws that are not synchronous between regulators and wastewater management operators; low funding for the construction of sanitation infrastructures, unclear tariffs for wastewater management, lack of interest from the private sectors to invest in the field of wastewater management, and low priority on domestic wastewater management.

Indonesian Government allocated an annual budget of around USD 31.1 billion for sanitation and hygiene sector in 2015, and it has been increasing owing to the Government target to reach Goal 6 of the SDGs about the provision and the improvement of sanitation and drinking water facilities. In achieving the SDGs target, every country, including Indonesia is expected to realise $100 \%$ access to sanitation for its population in 2030 (Irge, 2017). Investment needs for the sanitation universal access are estimated to reach 237.7 trillion, of which 202.4 trillion is allocated for investment in the field of wastewater management (PPSP, 2019).

Government of Indonesia has formulated an approach for domestic wastewater management. The approach classifies wastewater management into three schemes. Each scheme covers the different scale of management handled by different stakeholders (Figure 1). On-site and 
decentralised management is conducted at individual and neighbourhood level, while centralised management is meant for citywidescale. The selection of management approach depends on the population density and socioeconomic condition (Wahanudin and $\mathrm{Ph}$, 2014). For the area with low population density (rural) and low socio-economic condition, the individual and communal treatment become a choice. In a case, there is an increase in population density, the choice of wastewater management shifts towards decentralisation. For densely populated urban areas that exert an excellent socioeconomic condition, centralised management is viewed as the best choice according to government policies (Massoud, Tarhini and Nasr, 2009; Libralato, Volpi Ghirardini and Avezzù, 2012; Jung, Narayanan and Cheng, 2018). However, there is no governmental document that specifies the range of density and socio- economic conditions as a benchmark in determining the type of wastewater management suitable for a region. The next chapter discusses the regulation of wastewater management in Indonesia.

\section{WASTEWATER MANAGEMENT REGULATION AND POLICY RELATED TO WASTEWATER REUSE}

Table 1 presents a review of wastewater management regulations in some regions in Indonesia. The existing regulations and policies are reviewed according to their content and any articles discussing resource recovery. The existence of the regulations that support the adoption of wastewater resource recovery will foster the implementation as well as assure the safety of the sanitation products to be publicly used.

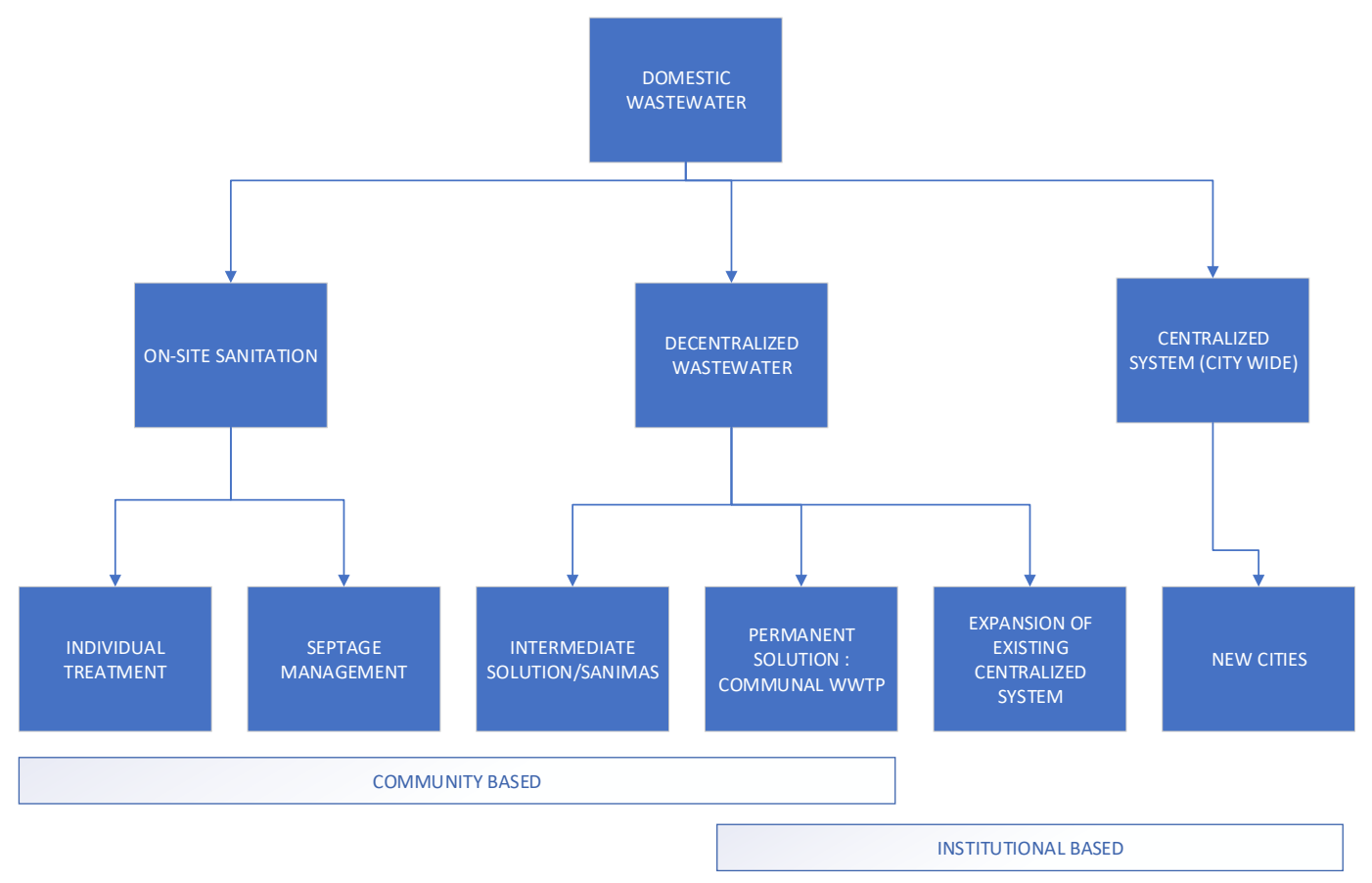

Figure 1. National Policy of Wastewater Management in Indonesia (Yudo and Said, 2017) 
Table 1. Wastewater Regulation and Policy Review

Regulation/Policy
Review Related to the Standard Practice of Wastewater Management and Implementation of Wastewater Resource Recovery

In addition to the regulation objective of disposing the treated wastewater safely, this regulation also aims to encourage efforts to reuse/recycle domestic wastewater treatment products.

This regulation encourages treatment sites that are close to the source of their waste, although the reasons for this are not explained

However, the recommended technical and financial studies carried out in this regulation do not include technical and economic studies for the concept of wastewater resource recovery.

Article No. 57 explains the utilization of domestic wastewater treatment results in liquid, solid and gas forms. However, technical utilisation of treated waste products is not explained in detail.

Wastewater management reporting does not cover quantification of treated waste products that are reused/recycled. The report mainly focuses on the quality of processed products discharged into the environment.

It does not quantitatively mention the availability of onsite wastewater treatment.

Ministry of Public Work \& Housing No. 14/2010 about Minimum Standards of Service

The scale standards for sanitation system (onsite, communal, offsite) is not clearly defined.

The standard suggests a mixing of greywater and blackwater for wastewater management.

Local regulation No. 20/2017 about wastewater management in Regency of Gunung Kidul, DIY

Empowering and monitoring program to enforce the effort of wastewater minimisation and to encourage the efficient use of natural resources and wastewater recycling.

In this regulation, there is a view that allows the direct discharge of the wastewater to drained pit and irrigation channel. On the contrary, the global trend leans toward separation between runoff and wastewater

Local regulation no. 13/2006 about wastewater management in Samarinda City (sanitary sewer) instead.

The determination of wastewater discharge fee is based on the wastewater volume and the quality index of the water body as well as the type of wastewater (municipal, commercial or industrial wastewater), and mainly focus on industrial wastewater.

Tariff for wastewater management is classified into several groups. The lowest fee applies to domestic and social groups that entail payment of Rp. 3,000,-/month, and the highest cost belongs to hotels, restaurants/industries, which demands a payment of 30,000,-/month. The wastewater treatment fee does not consider the volume of wastewater.

Tipping Fee of the wastewater treatment plant in Balikpapan City

The objective of this regulation is to control the wastewater discharge

Local regulation No 8/2018 about wastewater management in Depok and its quality, and none of the articles discusses the opportunity of resource recovery.

Regulation of The Governor of Special Regional Province Jakarta Capital Number 122 of 2005

The purpose of this regulation is more emphasized to the management of domestic wastewater to prevent and overcome soil and groundwater pollution from domestic sewage disposal that does not meet Wastewater Quality Standards. However, no article discusses the concept of WRR.

This regulation aims to control domestic wastewater discharge safely to

Regional Regulation of Bandung Regency Number 4 of 2013 about Domestic Wastewater Management the environment and to treat domestic wastewater as a resource. However, there is no discussion in the following articles related to the utilization of treated wastewater products.

Discharge fee is calculated based on the wastewater volume, pollution load, and the cost of environmental quality management, location index and nuisance index. The basic fare is Rp. $150 / \mathrm{m}^{3}$. This fee is low and potentially triggers people to choose discharge over recovery of their wastewater.
Local regulation No. 07/2007 about Permit of wastewater discharge in the City of Bekasi 
Table 1. Wastewater Regulation and Policy Review (continued)

\begin{tabular}{ll}
\hline Regulation/Policy & $\begin{array}{l}\text { Review Related to the Standard Practice of Wastewater Management } \\
\text { and Implementation of Wastewater Resource Recovery }\end{array}$ \\
\hline $\begin{array}{l}\text { DIY provincial regulation number } 2 \text { of } 2013 \\
\text { about Domestic Wastewater Management. }\end{array}$ & $\begin{array}{l}\text { The purpose of this regulation is only to regulate the results of } \\
\text { wastewater treatment for safe disposal to the environment. There is no } \\
\text { discussion related to the reuse of processed wastewater products. }\end{array}$ \\
$\begin{array}{l}\text { However, Article } 7 \text { regarding the management of wastewater mentions } \\
\text { about the utilisation of the recovered product. Nonetheless, it is unclear } \\
\text { which resource recovery technique is referred to in this article. }\end{array}$ \\
\hline
\end{tabular}

Arguably, domestic wastewater management regulations in Indonesia still emphasise on safe disposal of the treated wastewater. The criteria of safe disposal refer to the quality of wastewater discharge that should be under the threshold concentrations dictated by the national/provincial/local government. The concept of utilising treated wastewater products has been mentioned in the Minister of Public Works regulation and some provincial and City / Regency/ regional regulations. Yet, the technical and financial aspects related to the planning and implementation of wastewater recycling are not explained in detail. The application of the concept of wastewater resource recovery will be difficult without a strict regulation governing the reuse of resources from wastewater and sewage sludge.

\section{WASTEWATER RESOURCE RECOVERY AND ITS POTENTIAL USE IN INDONESIA}

In several developed countries, novel forms of existing resources are now abstracted from wastewater (Van Der Hoek, De Fooij and Struker, 2016; Puyol et al., 2017; Dolnicar, Hurlimann and Grün, 2011). Several resources can be extracted based on the dominant resource in wastewater characteristics and the demand for the waste product. Table 2 list the wastewater resources that can be extracted from wastewater. It is essential to understand the value of the recovered products compared to their quantity in wastewater to determine the most potential resources to be recovered. Figure 2 depicts various products that are ranked according to their value.

Table 2. Recovered Resources from Wastewater and Their Utilisation

\begin{tabular}{|c|c|c|c|c|}
\hline Recovered Resources & Pollutant Source & Recovery Process & Ultimate Use & References \\
\hline \multicolumn{5}{|l|}{ Water } \\
\hline Water & Wastewater & $\begin{array}{l}\text { Primary treatment- } \\
\text { biological treatment- } \\
\text { membrane-nutrient } \\
\text { removal (optional) }\end{array}$ & $\begin{array}{l}\text { Water, used for agriculture, } \\
\text { for industrial is used for } \\
\text { cooling water, groundwater } \\
\text { recharge, non-potable uses \& } \\
\text { potable uses. } \\
\text { Groundwater recharge, surface } \\
\text { water irrigation and industrial } \\
\text { cooling process } \rightarrow \text { effluent } \\
\text { from secondary treatment. }\end{array}$ & $\begin{array}{l}\text { IWA Report \& } \\
\text { Recovery } \\
(2016)\end{array}$ \\
\hline \multicolumn{5}{|l|}{ Energy } \\
\hline Bio $\mathrm{H}_{2}$ & Sewage Sludge & $\begin{array}{l}\text { Thermophilic } \\
\text { Anaerobic Digestion }\end{array}$ & $\begin{array}{l}\text { Used on-site to recover } \\
\text { electricity and heat the reactor }\end{array}$ & $\begin{array}{l}\text { Song et al. } \\
(2018)\end{array}$ \\
\hline Biogas & Sewage Sludge & $\begin{array}{l}\text { Mesophilic } \\
\text { Anaerobic Digestion }\end{array}$ & $\begin{array}{l}\text { Biogas majorly consists of } \\
\text { methane and carbon dioxide. } \\
\text { Methane can replace natural } \\
\text { gas to provide power \& heat. }\end{array}$ & $\begin{array}{l}\text { IWA Report \& } \\
\text { Recovery } \\
(2016)\end{array}$ \\
\hline Biochar & Sewage Sludge & $\begin{array}{l}\text { Acid bleaching- } \\
\text { separation }\end{array}$ & Fuel & $\begin{array}{l}\text { Song et al. } \\
(2018)\end{array}$ \\
\hline Biodiesel & Sewage Sludge & Transesterification & Fuel & $\begin{array}{l}\text { Song et al., } \\
(2018)\end{array}$ \\
\hline Nutrient & & & & \\
\hline
\end{tabular}


Table 2. Recovered Resources from Wastewater and Their Utilisation (continued)

\begin{tabular}{|c|c|c|c|c|}
\hline Recovered Resources & Pollutant Source & Recovery Process & Ultimate Use & References \\
\hline $\begin{array}{l}\text { Magnesium } \\
\text { ammonium phosphate } \\
\text { (MAP/struvite), } \\
\text { calcium phosphate, } \\
\text { iron phosphate }\end{array}$ & $\begin{array}{l}\text { Wastewater, urine, } \\
\text { ash, sewage sludge }\end{array}$ & $\begin{array}{l}\text { supercritical water } \\
\text { oxidation }\end{array}$ & Fertiliser & $\begin{array}{l}\text { IWA Report \& } \\
\text { Recovery, } \\
\text { (2016); Amann } \\
\text { et al., (2018); } \\
\text { Batstone, } \\
\text { Hülsen, Mehta, } \\
\text { \& Keller, } \\
\text { (2015); Cieślik } \\
\text { \& Konieczka, } \\
\text { (2017); Kataki, } \\
\text { West, Clarke, } \\
\text { \& Baruah, } \\
\text { (2016); } \\
\text { Rahman et al., } \\
\text { (2014) }\end{array}$ \\
\hline $\begin{array}{l}\text { Fertilizer grade } \\
\text { ammonium sulphate }\end{array}$ & $\begin{array}{l}\text { Sludge } \\
\text { Wastewater }\end{array}$ & $\begin{array}{l}\text { sludge digestion } \\
\text { process by stripping } \\
\text { and adsorption } \\
\text { nitration and } \\
\text { anammox } \\
\text { (autotrophic } \\
\text { denitrification) }\end{array}$ & Fertiliser & $\begin{array}{l}\text { IWA Report \& } \\
\text { Recovery } \\
(2016)\end{array}$ \\
\hline Stripped ammonia & Wastewater & $\begin{array}{l}\text { condensation, } \\
\text { absorption or } \\
\text { oxidation }\end{array}$ & Concentrated fertiliser & $\begin{array}{l}\text { IWA Report \& } \\
\text { Recovery, } \\
\text { (2016); Mehta, } \\
\text { Khunjar, } \\
\text { Nguyen, Tait, } \\
\text { \& Batstone, } \\
\text { (2015); Yan et } \\
\text { al., (2018) }\end{array}$ \\
\hline Nitrate/Nitrite & Wastewater & $\begin{array}{l}\text { liquid-liquid } \\
\text { extraction } \\
\text { technologies }\end{array}$ & fertiliser & $\begin{array}{l}\text { IWA Report \& } \\
\text { Recovery, } \\
(2016) ; \text { Mehta } \\
\text { et al., (2015); } \\
\text { Yan et al., } \\
\text { (2018) }\end{array}$ \\
\hline \multicolumn{5}{|l|}{ Metal } \\
\hline Metal sulphides & Sewage sludge & $\begin{array}{l}\text { Biological treatment } \\
\text { using sulphate } \\
\text { reducing bacteria }\end{array}$ & Fine chemical for Industry & $\begin{array}{l}\text { IWA Report \& } \\
\text { Recovery } \\
(2016)\end{array}$ \\
\hline $\mathrm{Cr}$ and $\mathrm{Cu}$ & Sewage sludge & Electrodialysis & & \\
\hline Noble metals & Sewage sludge & Photocatalysis & & \\
\hline Any other metals & Sewage sludge & $\begin{array}{l}\text { HMRT (heavy metals } \\
\text { recovery } \\
\text { technologies): ion } \\
\text { exchange, leaching, } \\
\text { adsorption, magnetic } \\
\text { nanoparticles and } \\
\text { foam fractionation }\end{array}$ & & \\
\hline \multicolumn{5}{|l|}{ Other Material } \\
\hline $\begin{array}{l}\text { Biodegrabale Polymer } \\
\text { (Bioplastic)- } \\
\text { Polyhydroxilalkanoates } \\
\text { (PHA) }\end{array}$ & Sewage sludge & $\begin{array}{l}\text { Biological treatment. } \\
\text { Bacteria are } \\
\text { introduced to harsh } \\
\text { growth condition due } \\
\text { to limited } \\
\text { phosphorus and }\end{array}$ & Industrial Material & $\begin{array}{l}\text { IWA Report \& } \\
\text { Recovery } \\
(2016)\end{array}$ \\
\hline
\end{tabular}


Table 2. Recovered Resources from Wastewater and Their Utilisation (continued)

\begin{tabular}{|c|c|c|c|c|}
\hline Recovered Resources & Pollutant Source & Recovery Process & Ultimate Use & References \\
\hline & & $\begin{array}{l}\text { nitrogen, and there is } \\
\text { an excess of carbon } \\
\text { sources such as } \\
\text { glucose and proteins }\end{array}$ & & \\
\hline $\begin{array}{l}\text { Hydrogen, hydrogen } \\
\text { peroxide, caustic } \\
\text { solution, sulphate, } \\
\text { metal) }\end{array}$ & Sewage sludge & $\begin{array}{l}\text { MET (microbial } \\
\text { electrochemical } \\
\text { technologies), for } \\
\text { example, microbial } \\
\text { electrodialysis cells } \\
\text { (MEC) }\end{array}$ & Industrial chemical & $\begin{array}{l}\text { IWA Report \& } \\
\text { Recovery } \\
(2016)\end{array}$ \\
\hline Cellulose fibres & Sewage sludge & $\begin{array}{l}\text { Before cellulose is } \\
\text { metabolised, it needs } \\
\text { to be hydrolysed and } \\
\text { this process, to a } \\
\text { large extent, depends } \\
\text { on temperature and } \\
\text { sludge retention time }\end{array}$ & Textile Industry & $\begin{array}{l}\text { IWA Report \& } \\
\text { Recovery } \\
(2016)\end{array}$ \\
\hline Alginic acid & Granular sludge & Nereda process & For the food industry & $\begin{array}{l}\text { Van Der Hoek } \\
\text { et al. (2016) }\end{array}$ \\
\hline
\end{tabular}

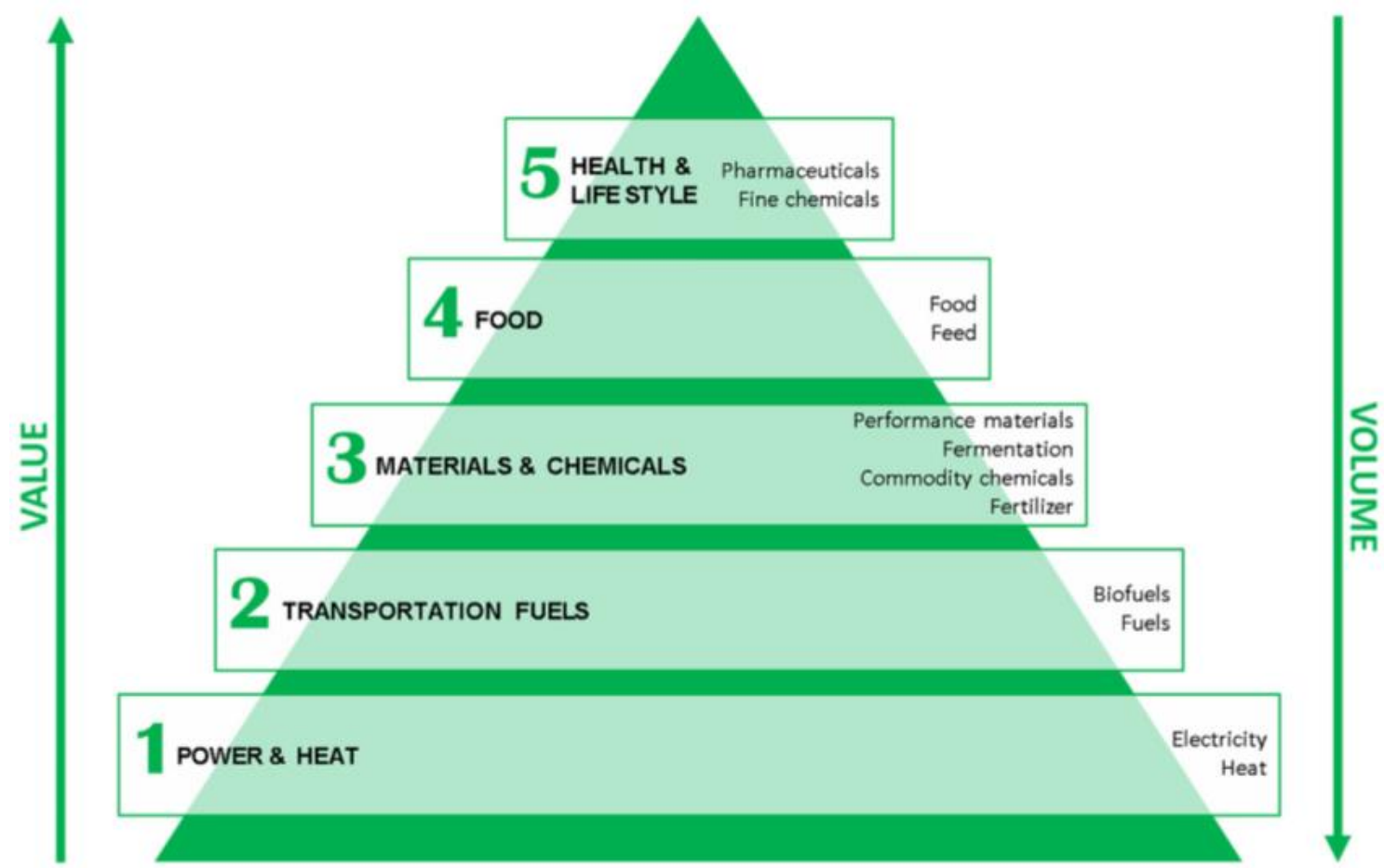

Figure 2. Value Pyramid (Van Der Hoek, De Fooij and Struker, 2016)

Although produced in small daily amounts, human excreta contain high amounts of nutrients which can be recovered as valuable resources for agriculture. By using a urine diversion toilet, urine and fecal matter were collected and treated separately in a pilot-plant scale in Surabaya, Indonesia. A study conducted by Malisie et al (2007) in Surabaya, describes the potential of nutrient recovery from human excreta. It was found that using diverting toilet, up to $86 \%$ nitrogen, $21 \%$ phosphorus, and $69 \%$ potassium can be recovered from Urine and 12\% nitrogen, $68 \%$ phosphorus and $20 \%$ potassium can be recovered from fecal matter. In addition, Study from Kerstens et al., (2016b) estimates that recoverable products can cover the forecasted 
demand in 2035 of phosphorus (15\%), compost (35\%), duckweed (7\%), plastic (66\%) and paper (18\%). While the disadvantage of the recovered product was highlighted by the study (Kerstens et al., 2016b) in which the Total Lifecycle Cost of recovered product is considered to be still expensive. According to a study by Kerstens et al (2015a), a 4 fold increase in the recovered resource selling price will increase 1.3 times higher TLC. The problem of low skill labour to operate and maintain the facility of wastewater system including the treatment and recovery plant was also a barrier in the application of WRR.

According to the study conducted by Kerstens et al. (2016), the demand for the fertiliser for food crops, plantation and horticulture in Indonesia is high, and the supply is much lesser than the demand. In total for three sectors of agriculture (food crops, plantation and horticulture), the demand for nitrogen is $1,459 \mathrm{kt} /$ year; phosphorus is $295 \mathrm{kt} /$ year, potassium is $905 \mathrm{kt} /$ year, and compost is $27,984 \mathrm{kt} /$ year. Knowing the demand and supply of recoverable resources may create an awareness of the availability and sustainability of the resources. Wastewater and sewage sludge are potential sources of these materials. Ignoring the resources in wastewater and sewage sludge may jeopardise the security of food supply (Kerstens, Leusbrock and Zeeman, 2015b). However, the biggest challenge in the implementation of wastewater resources recovery in Indonesia includes social acceptability of the waste product, particularly issues pertaining to health and distance between supply and demand location (Agudelo-Vera et al., 2011).

The issues of acceptability of the waste product used arise not only in Indonesia but are also experienced by some other countries. The reason behind the refusal of waste products is circling around the hygienisation process of sanitation by-products and, in some countries, religion is also one of the barriers for the implementation of wastewater resource recovery (Adewumi, Ilemobade and Van Zyl, 2010; Garcia and Pargament, 2015; Haider et al., 2018; Guest et al., 2009; Dolnicar, Hurlimann and Grün, 2011). Proximity issues between supply and demand emerge in Indonesia owing to its geographical conditions as an archipelago and lead to imbalanced supply and demand (Kerstens et al., 2016a). The concept of the circular economy should greatly benefit from the proximity between the supply and demand location (Kerstens, Leusbrock and Zeeman, 2015b). Many agriculture lands in Indonesia in need of a supply of N, P, K and compost are located far away from the location of supply. Take phosphorus as an example. Phosphorus can be recovered as struvite, slow phosphorus releasing fertiliser. Domestic wastewater and sludge sewage contain a high amount of phosphorus (Tansel, Lunn and Monje, 2018; Zhou et al., 2017; Kataki et al., 2016). The demand for phosphorus is high in Sumatra, followed by Java and Kalimantan (Kerstens et al., 2016a). However, only $27 \%$ of the total population of Indonesia live in Sumatra (BPS, 2013); hence, the recovery potential of phosphorus is not that high in Sumatra. Urbanized area is a potential area for phosphorus supply; however, it does not have space to develop agriculture area. Java island is an island with high population density with a lesser area for agriculture; therefore, discharge of treated wastewater along with the resources contained into the environment is a common practice for wastewater treatment plants in Java. Thus, the strategy to close the gap between supply and demand of resources recovered from wastewater must be developed to assure the effectiveness of wastewater resource recovery implementation.

\section{GLOBAL TREND OF DOMESTIC WASTEWATER MANAGEMENT}

Several new global wastewater management trends implemented worldwide have not found ground in Indonesia. Wastewater management that focuses on resource recovery is mainly developed in decentralised systems (Massoud, Tarhini and Nasr, 2009; Libralato, Volpi Ghirardini and Avezzù, 2012). Decentralised systems will reduce the cost of sewage transport thanks to the close vicinity to the potential users of the sanitation products. A total of approximately 1700 decentralised wastewater treatment systems have been constructed until 
2015. In 2016, new wastewater plants were built at 753 locations spread across various provinces in Indonesia through the SANIMAS (CommunityBased Sanitation Project) (Eales et al., 2013).

The use of decentralised and satellite systems will allow treated wastewater reuse, making them a stable and sustainable water source, especially for those areas that historically suffer or have recently been suffering from water scarcity (Libralato, Volpi Ghirardini and Avezzù, 2012). At present, the centralised wastewater management systems are located in only 12 cities with low service coverage $( \pm 15 \%)$ (Eales et al., 2013). Decentralised treatment is principally defined by the fact that raw wastewater is treated next to the source (Wilderer and Schreff, 2000). The wastewater collection system is still required, but the use of large and long pipes can be avoided, as well as the related excavation works to create a more or less composite collection system network (Libralato, Volpi Ghirardini and Avezzù, 2012). Some criticisms have highlighted the existing regulations, which are generally lacking to accommodate the decentralisation processes. The lack of regulation affects decentralised system management that includes its daily operation and maintenance. Further, some literature stated the performance of decentralised systems does not always reach very high-quality standards owing to the lack of maintenance (Mitchell et al., 2008).

Related to the basic consideration of wastewater treatment design, organic removal is a likely design indicator while pathogenic content is mostly forgotten. The treatment plant should not only focus on the removal of organic, but it should incorporate a treatment system that minds about the pathogenic content in the wastewater (Mitchell and Ross, 2016). Thus, the design criteria should accommodate those pathogenic indicators. Pathogenic content in the wastewater could cause detrimental effects of the sanitation products following their use. One of the biggest challenges in implementing wastewater resource recovery is the acceptability of sanitation product due to the health risk of pathogen infection (Smith et al., 2018; Dolnicar, Hurlimann and Grün, 2011; Garcia and Pargament, 2015;
Adewumi, Ilemobade and Van Zyl, 2010). Therefore, treatment systems with pathogenic removal orientation will reduce the health risk of sanitation product.

Many countries have applied a separate sewer system that carries the sewage to the wastewater treatment plant (Libralato, Volpi Ghirardini and Avezzù, 2012). A separate sewer system minimises the impact of sewer overflow that can pollute the receiving water body. Potential eutrophication phenomena may occur in the receiving water body due to the large volumes of treated wastewater discharged (Wilderer and Schreff, 2000; Libralato, Volpi Ghirardini and Avezzù, 2012); in some case of combined sewer flow, diluted wastewater requires more expensive treatment approaches (Libralato, Volpi Ghirardini and Avezzù, 2012; Massoud, Tarhini and Nasr, 2009).

The trend of global wastewater management involves the plan for resource recovery of products in any form such as liquid, solid or gas (De Zeeuw, Van Veenhuizen and Dubbeling, 2011; Cordell et al., 2011; Garcia and Pargament, 2015; Guest et al., 2009). The concept of wastewater resource recovery offers the formation of sustainable and resilient communities by utilising any resources that can be recovered from wastewater. According to a study by Gerbens-Leenes et al. (2010), Report \& Recovery (2016) and Van Der Hoek et al., (2016), there are many resources contained in wastewater and each has an economic value (Gerbens-Leenes, Nonhebel and Krol, 2010; Van Der Hoek, De Fooij and Struker, 2016; Report and Recovery, 2016). If the wastewater management incorporates the wastewater resources recovery concept, participation from the community can be expected since they get the benefits from processing and utilising the resources in water, e.g. water and biogas. From the business point of view, if the mastery of recovery technology has matured, the wastewater can become a source of fertiliser and raw materials for many industries, e.g. paper and pharmaceutical industry. The most significant component of wastewater treatment is a large amount of energy needed to operate a 
waste treatment plant. If the WRR concept is adopted, wastewater treatment can produce an alternative energy source. In some overseas water treatment, energy production from surplus wastewater can even be used by the surrounding community ( $\mathrm{Gu}$ et al., 2017). With the implementation of WRR, the processing costs will be lower, resulting in lower tariffs charged to the community (Garcia and Pargament, 2015; Gu et al., 2017; Guest et al., 2009; Puyol et al., 2017)

\section{CONCLUSION}

Wastewater resource recovery becomes a global trend considering many valuable resources it contains. In Indonesia, the implementation of wastewater resource recovery is constrained by problems with wastewater management. Several issues have been identified in this paper such as low public awareness and participation, lack of laws, regulation and standard, absence of a clear framework to help the decision-makers, gaps in the regulation and implementation, funding issues of the construction, operation and maintenance and low priority on domestic wastewater handling.

Resource recovery from wastewater is not a new case worldwide. Wastewater contains a high load of nitrogen, phosphorus, potassium, among other materials that are essentially the ingredients for fertiliser. Further, its resource can generate various products such as energy, heat and valuable materials like metal, alginic acid and cellulose fibre. However, the implementation of wastewater resource recovery in Indonesia has two significant challenges related to the social acceptability and distance between supply and demand. Indonesia as an archipelago country has a high demand for fertiliser in the area which has less population. Phosphorus, nitrogen and potassium can be extracted from sewage sludge or wastewater; unfortunately, these wastewater and sludge treatment plants are mostly located in the urbanised area. The distance gap between the location of supply and demand creates a barrier to the effective management of wastewater resource recovery.
Moreover, the regulations and policies in Indonesia do not support the implementation of WRR. Some regulations have mentioned the utilisation of sanitation product; however, they do not explain the technical and financial aspect related to WRR. The global trend of wastewater management urging not only treatment of wastewater but also utilisation of the recovered resources is increasingly implemented nowadays. Therefore, all the obstacles for the implementation of WRR in Indonesia should be identified, and the solution for an effective and new wastewater management blueprint must be constructed. According to this study, the most important thing to support the implementation of WRR is to construct a set of regulations promoting WRR, and in parallel, education for the users should be conducted.

\section{DISCLAIMER}

The authors declare no conflict of interest.

\section{ACKNOWLEDGMENTS}

The author would like to thank the Civil and Environmental Engineering Department, Universitas Gadjah Mada for providing a research fund for this paper.

\section{REFERENCES}

ADB, 2017. Urban wastewater management in Indonesia: Key principles and issues in Drafting local regulations.

Adewumi, J.R., Ilemobade, A.A. and Van Zyl, J.E., 2010. Treated wastewater reuse in South Africa: Overview, potential and challenges. Resources, Conservation and Recycling, 55(2), pp.221-231.

AECOM International Development and Sandec, 2010. A Rapid Assessment of Septage Management in Asia.

Afandi, Y.V. and Sunoko, H.R., 2013. Pengelolaan Air Limbah Domestik Komunal Berbasis Masyarakat di Kota Probolinggo. 26(1), pp.97102.

Agudelo-Vera, C.M., Mels, A.R., Keesman, K.J. and Rijnaarts, H.H.M., 2011. Resource management as a key factor for sustainable urban 
planning. Journal of Environmental Management, 92(10), pp.2295-2303.

Amann, A., Zoboli, O., Krampe, J., Rechberger, H., Zessner, M. and Egle, L., 2018. Environmental impacts of phosphorus recovery from municipal wastewater. Resources, Conservation and Recycling, 130(December 2017), pp.127-139.

Bappenas, 2014. Draft RPJMN 2015-2019 and Target Universal Access AMPL. Jakarta.

Batstone, D.J., Hülsen, T., Mehta, C.M. and Keller, J., 2015. Platforms for energy and nutrient recovery from domestic wastewater: A review. Chemosphere, 140, pp.2-11.

Bons, K.C.A. (Deltares), Soekmono, A., Azhari, N., Restiawan, A., Tunggal, L., Yazid, A., Dini Uljati, I., Tata Samiadji, B., Tangkas, P., Suryana, Aart van, N., Muijtjens, R., de Groot, D., HaskoningDHV), S. (Royal, de Bel, M. and Brinkman, J. (Deltares), 2016. Asian Development Bank Indonesia - Country Water assessment Indonesia Country Water assessment.

BPS, 2013. Proyeksi Penduduk Indonesia Indonesia Population Projection.

Braungart, M., McDonough, W. and Bollinger, A., 2007. Cradle-to-cradle design: creating healthy emissions - a strategy for eco-effective product and system design. Journal of Cleaner Production, 15(13-14), pp.1337-1348.

Cieślik, B. and Konieczka, P., 2017. A review of phosphorus recovery methods at various steps of wastewater treatment and sewage sludge management. The concept of "no solid waste generation" and analytical methods. Journal of Cleaner Production, 142, pp.1728-1740.

Cordell, D., Rosemarin, A., Schröder, J.J. and Smit, A.L., 2011. Towards global phosphorus security: A systems framework for phosphorus recovery and reuse options. Chemosphere, 84(6), pp.747-758.

Dolnicar, S., Hurlimann, A. and Grün, B., 2011. What affects public acceptance of recycled and desalinated water? Water Research, 45(2), pp.933-943.

Eales, K., Isabel, B., Reini, S. and Evi, F., 2013.
Review of Community-Managed Decentralized Wastewater Treatment Systems in Indonesia. Technical Paper, (June), pp.1-32.

Garcia, X. and Pargament, D., 2015. Reusing wastewater to cope with water scarcity: Economic, social and environmental considerations for decision-making. Resources, Conservation and Recycling, 101, pp.154-166.

Gerbens-Leenes, P.W., Nonhebel, S. and Krol, M.S., 2010. Food consumption patterns and economic growth. Increasing affluence and the use of natural resources. Appetite, 55(3), pp.597608.

Governor Regulation No. 2/2013 about Domestic Wastewater Management.

Governor Regulation of DKI Jakarta No. 122/2005 about Domestic Wastewater Management.

Gu, Y., Li, Y., Li, X., Luo, P., Wang, H., Wang, X., $\mathrm{Wu}$, J. and Li, F., 2017. Energy Self-sufficient Wastewater Treatment Plants: Feasibilities and Challenges. In: Energy Procedia. pp.3741-3751.

Guest, J.S., Skerlos, S.J., Barnard, J.L., Beck, M.B., Daigger, G.T., Hilger, H., Jackson, S.J., Karvazy, K., Kelly, L., Macpherson, L., Mihelcic, J.R., Pramanik, A., Raskin, L., Van Loosdrecht, M.C.M., Yeh, D. and Love, N.G., 2009. A new planning and design paradigm to achieve sustainable resource recovery from wastewater. Environmental Science and Technology, 43(16), pp.6126-6130.

Haider, H., Alsaleem, S.S., Ghumman, A.R. and Sadiq, R., 2018. Development of Consumer Perception Index for assessing greywater reuse potential in arid environments. 44(4).

Van Der Hoek, J.P., De Fooij, H. and Struker, A., 2016. Wastewater as a resource: Strategies to recover resources from Amsterdam's wastewater. Resources, Conservation and Recycling, 113, pp.53-64.

Irge Olga Aujouannet Director, 2017. SDG implementation in G20 countries Status Spring 2017.

Jung, Y.T., Narayanan, N.C. and Cheng, Y.L., 2018. Cost comparison of centralized and 
decentralized wastewater management systems using optimization model. Journal of Environmental Management, 213, pp.90-97.

Kataki, S., West, H., Clarke, M. and Baruah, D.C., 2016. Phosphorus recovery as struvite: Recent concerns for use of seed, alternative Mg source, nitrogen conservation and fertilizer potential. Resources, Conservation and Recycling, 107, pp.142-156.

Kerstens, S.M., Leusbrock, I. and Zeeman, G., 2015a. Feasibility analysis of wastewater and solid waste systems for application in Indonesia. Science of the Total Environment, 530-531, pp.5365.

Kerstens, S.M., Leusbrock, I. and Zeeman, G., 2015b. Feasibility analysis of wastewater and solid waste systems for application in Indonesia. Science of The Total Environment, 530-531, pp.5365.

Kerstens, S.M., Priyanka, A., van Dijk, K.C., De Ruijter, F.J., Leusbrock, I. and Zeeman, G., 2016a. Potential demand for recoverable resources from Indonesian wastewater and solid waste. Resources, Conservation and Recycling, 110, pp.16-29.

Kerstens, S.M., De Ridder, R., Hof, A., Alberts, J., Mulhall, D. and Dale, D., 2011. Towards ecoeffective sustainable sanitation for the city of Almere. Water Practice and Technology, 6(2).

Kerstens, S.M., Spiller, M., Leusbrock, I. and Zeeman, G., 2016b. A new approach to nationwide sanitation planning for developing countries: Case study of Indonesia. Science of the Total Environment, [online] 550, pp.676-689. Available at: <http://dx.doi.org/10.1016/j.scitotenv.2016.01.10 $4>$.

Libralato, G., Volpi Ghirardini, A. and Avezzù, F., 2012. To centralise or to decentralise: An overview of the most recent trends in wastewater treatment management. Journal of Environmental Management, 94(1), pp.61-68.

Local Regulation No. 13/2006 about Wastewater Mangement in the City of Samarinda.
Malisie, A.F., Prihandrijanti, M. and Otterpohl, R., 2007. The potential of nutrient reuse from a source-separated domestic wastewater system in Indonesia - Case study: Ecological sanitation pilot plant in Surabaya. Water Science and Technology, 56(5), pp.141-148.

Massoud, M.A., Tarhini, A. and Nasr, J.A., 2009. Decentralized approaches to wastewater treatment and management: Applicability in developing countries. Journal of Environmental Management, 90(1), pp.652-659.

McDonough, 2000. Cradle to cradle: Remaking the way we make things: - Google Cendekia.

Mehta, C.M., Khunjar, W.O., Nguyen, V., Tait, S. and Batstone, D.J., 2015. Technologies to recover nutrients from waste streams: A critical review. Critical Reviews in Environmental Science and Technology, 45(4), pp.385-427.

Ministrial Regulation No. 18/2007 about Development of Water Supply System.

Ministrial Regulation No.04/2017 about Domestic Wastewater Management.

Mitchell, C., Retamal, M., Fane, S., Willetts, J. and Davis, C., 2008. Decentralised water systemscreating conducive institutional arrangements. Institute for Sustainable Futures, University of Technology, Sydney. Accessed November, 10, p.2011.

Mitchell, C. and Ross, K., 2016. Findings and Recommendations. A synthesis for key stakeholders in community scale sanitation in Indonesia. pp.1-13.

Murray, A. and Ray, I., 2010. Commentary: Backend users: The unrecognized stakeholders in demand-driven sanitation. Journal of Planning Education and Research, 30(1), pp.94-102.

PPSP, 2019. No Title. Portal Sanitasi Indonesia.

Puyol, D., Batstone, D.J., Hülsen, T., Astals, S., Peces, M. and Krömer, J.O., 2017. Resource recovery from wastewater by biological technologies: Opportunities, challenges, and prospects. Frontiers in Microbiology, . 
Rahman, M.M., Salleh, M.A.M., Rashid, U., Ahsan, A., Hossain, M.M. and Ra, C.S., 2014. Production of slow release crystal fertilizer from wastewaters through struvite crystallization - A review. Arabian Journal of Chemistry, 7(1), pp.139-155.

Report, A.C. and Recovery, R., 2016. IWA Resource Recovery Cluster State of the Art Compendium Report on Resource Recovery from Water Preface. p.49.

Smith, H.M., Brouwer, S., Jeffrey, P. and Frijns, J., 2018. Public responses to water reuse Understanding the evidence. Journal of Environmental Management, 207, pp.43-50.

Song, X., Luo, W., Hai, F.I., Price, W.E., Guo, W., Ngo, H.H. and Nghiem, L.D., 2018. Resource recovery from wastewater by anaerobic membrane bioreactors: Opportunities and challenges. Bioresource Technology, 270(September), pp.669-677.

Tansel, B., Lunn, G. and Monje, O., 2018. Struvite formation and decomposition characteristics for ammonia and phosphorus recovery: A review of magnesium-ammonia-phosphate interactions. Chemosphere, 194, pp.504-514.

The World Bank; Australian Aid, 2013. East Asia Pacific Region Urban Sanitation Review : Indonesia Country Study.

Thornton, P.K., 2010. Livestock production: Recent trends, future prospects. Philosophical Transactions of the Royal Society B: Biological
Sciences, 365(1554), pp.2853-2867.

Wahanudin, I. and Ph, M.M.S., 2014. Indonesia National Policy on Sanitation Development. (March).

Wahyu Wijaya, I.M., 2018. Domestic Wastewater in Indonesia: Challenge in the Future Related To Nitrogen Content. International Journal of GEOMATE, 15(47), pp.32-41.

Wilderer, P.A. and Schreff, D., 2000. Decentralized and centralized wastewater management: a challenge for technology developers. Water Science and Technology, 41(1), pp.1-8.

Yan, T., Ye, Y., Ma, H., Zhang, Y., Guo, W., Du, B., Wei, Q., Wei, D. and Ngo, H.H., 2018. A critical review on membrane hybrid system for nutrient recovery from wastewater. Chemical Engineering Journal, 348(December 2017), pp.143-156.

Yudo, S. and Said, N.I., 2017. Kebijakan dan Strategi Pengelolaan Air Limbah Domestik di Indonesia. 10(2), pp.58-75.

De Zeeuw, H., Van Veenhuizen, R. and Dubbeling, M., 2011. The role of urban agriculture in building resilient cities in developing countries. Journal of Agricultural Science, 149(S1), pp.153-163.

Zhou, K., Barjenbruch, M., Kabbe, C., Inial, G. and Remy, C., 2017. Phosphorus recovery from municipal and fertilizer wastewater: China's potential and perspective. Journal of Environmental Sciences (China), 52, pp.151-159. 